DOI: http://dx.doi.org/10.15688/jvolsu4.2016.2.7

UDC 929.5+929.6+947.06+947.081/.083(471.331)

Submitted: 12.01 .2016

LBC 63.214+63.215+63.3(2)47+63.3(2)52

Accepted: 14.03 .2016

\title{
VOSKRESENSKY NEW JERUSALEM MONASTERY: PLACE OF PRINCE A.A. CHELAKAEV (CHELOKAEV) IN THE FAMILY NECROPOLIS OF THE BUTURLINS - PRIKLONSKYS - VOLYNSKYS - WOLFS - SUKHOVO-KOBYLINS
}

\author{
Viktor V. Murzin-Gundorov \\ Assistant Professor, Department of History, \\ Orthodox Institute of Saint John the Evangelist \\ murgund@mail.ru \\ Chernyshevskogo Lane, 11a, 127473 Moscow, Russian Federation
}

\begin{abstract}
Our research of necropolis of New Jerusalem Monastery has brought a new name. It is prince A.A. Chelakaev. He was buried on the unpaved section of the monastery cemetery. Historic burial place of one of the oldest princely family of Georgia in a noble part of monastery necropolis let us attribute prince A.A. Chelakaev to related families - the Buturlins - Priklonskys - Volynskis - Wolfs - Sukhovo-Kobylins (25/10/1778 - 04/11/1873), including 11 graves. Besides, that extends investigations based on the "monument / burial" principle.

Genealogical research that affected the person buried in the monastery of Prince Alexander Anofrievich Chelakaev allowed to make up for the genealogy of Chelokashvili princes, one of the most noble families of Georgia so far very poorly studied. We used the sources associated with burials in Moscow the Georgian elite tombs of St. Nicholas Greek and the Donskoy Monastery. Georgian prince, buried in the Voskresensky New Jerusalem Monastery, was not an unauthorized person to a host of representatives of persons belonging to the aristocracy reigning House of Bagration.

We note that the research material at our disposal expanded the results of archaeological discoveries of 20092013. Due to this facxt, we updated the list of monuments involving research field associated with the study of the necropolis of the New Jerusalem Monastery in the genealogical, heraldic and epigraphic monuments from 1656 to 1919, as we attributed several previously unknown and inaccessible tombstones before hidden in the ground. In particular, the findings of two new graves and tombstones proved to be especially valuable.

Key words: necropolis, Voskresensky New Jerusalem Monastery, monument, sources, genealogy, heraldry,
\end{abstract} epigraphy, Chelakaev.

\section{ВОСКРЕСЕНСКИЙ НОВО-ИЕРУСАЛИМСКИЙ МОНАСТЫРЬ: МЕСТО КНЯЗЯ А.А. ЧЕЛАКАЕВА (ЧЕЛОКАЕВА) \\ В ФАМИЛЬНОМ НЕКРОПОЛЕ БУТУРЛИНЫХ - ПРИКЛОНСКИХ - ВОЛЫНСКИХ - ВУЛЬФ - СУХОВО-КОБЫЛИНЫХ}

\author{
Виктор Владимирович Мурзин-Гундоров \\ Старший преподаватель кафедры истории, \\ Православный институт святого Иоанна Богослова \\ murgund@mail.ru \\ пер. Чернышевского, 11a, 127473 г. Москва, Российская Федерация
}

Аннотация. Предпринятое нами исследование некрополя Воскресенского Ново-Иерусалимского монастыря позволило выявить новую персоналию в лице князя Александра Анофриевича Челакаева, погре- 
бенного на грунтовом участке монастырского кладбища. Историческое место захоронения представителя одного из древнейших княжеских домов Грузии в дворянской части некрополя позволяет сопричесть князя к родственному клану семей Бутурлиных - Приклонских - Волынских - Вульф - Сухово-Кобылиных (25.10.1778 11.04.1873), включающему 11 захоронений. Помимо этого расширяется поле исследования по принципу памятник/погребение.

Генеалогические изыскания, затронувшие личность погребенного в монастыре князя Александра Анофриевича Челакаева, позволили нам восполнить родословную князей Челокашвили, одной из самых знатных фамилий Грузии, до настоящего времени весьма плохо изученную. Для работы мы использовали источники, связанные с захоронениями грузинской элиты в московских усыпальницах Николо-Греческого и Донского монастырей. Погребенный в Воскресенском Ново-Иерусалимском монастыре грузинский князь оказался не посторонним лицом для целого сонма представителей аристократии, принадлежащих к лицам владетельного дома Багратионов.

В своей работе мы обращаем внимание на то, что имеющийся в нашем распоряжении материал для проведения исследований существенно расширил результаты археологических открытий 2009-2013 годов: пополнился перечень памятников, затрагивающих исследовательское поле, связанное с изучением некрополя Воскресенского Ново-Иерусалимского монастыря в системе генеалогических, геральдических и эпиграфических памятников 1656-1919 годов, поскольку были атрибутированы несколько ранее неизвестных и недоступных надгробий, до того скрытых в земле. В частности, особенно ценными оказались находки, составившие два новых захоронения и надгробья.

Ключевые слова: некрополь, Воскресенский Ново-Иерусалимский монастырь, памятник, источники, генеалогия, геральдика, эпиграфика, Челакаев.

Воскресенский Ново-Иерусалимский монастырь в истории Российского государства занял особое место, также как и в истории вселенского христианства. Он стал уникальным и единственным в своем роде, не знающим себе равных в мировой культуре воплощенным проектом историко-художественного комплекса с глубинным богословским замыслом перенесения Палестинских Святынь. Именно в этом памятнике выразилось созидание Святой Руси и превращение ее в Новую Святую Землю. Подмосковный Иерусалим стал материальным фактом духовного закрепления Россией модели будущей Великой России - Вселенской хранительницы святого Православия.

Наше исследование посвящено изучению одного из компонентов некрополя Воскресенского Ново-Иерусалимского монастыря, так как в настоящее время некрополь является важнейшей и неотъемлемой частью мирового исторического и культурного наследия [16, c. 224-225, 232]. В современное определение некрополя принято включать не только совокупность захоронений и памятников, но и целый спектр источников в системе культурных ценностей той или иной эпохи. Так, некрополь Воскресенского Ново-Иерусалимского монастыря напрямую связан с одной из самых ярких исторических личностей, крупным деяте- лем отечественной истории XVII столетия Святейшим Патриархом Никоном. Именно он в 1654 г. был удостоен титула «великого государя». На отрезке 1654-1658 гг. он же во время военных действий Русско-польской войны в отсутствии царя управлял государством, продолжая по факту оставаться вторым великим государем.

Самостоятельная история некрополя Нового Иерусалима начинается с погребения Святейшего Патриарха Никона и его гробницы. Монастырское кладбище Нового Иерусалима составляет единое целое с некрополем внутри храмов. Дворянский некрополь связан с именами вкладчиков-мирян и почитателей памяти Патриарха Никона, погребенных в придельных церквах Воскресенского собора, а также в склепах на открытых участках обители [19]. Монастырский некрополь стал местом упокоения целого ряда представителей исторических фамилий русской аристократии [17, с. 141-144]. Погребения находятся не только в Воскресенском соборе и «Вифлеемских» приделах на первом этаже трапезного храма Рождества Христова [7, с. 182, 394]. В Новом Иерусалиме под храмом Рождества Христова был устроен Святой Вертеп и приделы по вифлеемскому образцу, в том числе церковь в честь Мучеников 14000 младенцев, от Ирода в Вифлееме избиенных [22, с. 549]. 
В соответствии с первообразом именно этот придел стал усыпальницей в XVIII-XIX веках.

Предпринятое нами исследование некрополистического комплекса Воскресенского Ново-Иерусалимского монастыря, охватывающее внутрихрамовые и грунтовые захоронения 1656-1918 гг., позволило выявить новую персоналию в лице князя Александра Анофриевича Челакаева (именно так его фамилия указана на надгробии).

Цель настоящей работы состоит в определении причины погребения в 1789 г. и исторического места в дворянской части некрополя Воскресенского Ново-Иерусалимского монастыря представителя одного из древнейших княжеских домов Грузии, принадлежавшего к родственному клану семей Бутурлиных - Приклонских - Волынских - Вульф Сухово-Кобылиных (25.10.1778 - 11.04.1873), включающему 11 захоронений.

Работа над определением проблемы становления семейных, фамильных, родовых и одиночных дворянских захоронений в системе монастырского некрополя Нового Иерусалима позволила выделить ряд самостоятельных усыпальниц, каждой из которых было дано авторское определение и соответствующая классификация в соответствии с хронологическим отрезком факта захоронений $[11$, ф. 1 , оп. 1 , д. 507 , л. 1]. Также было произведено документальное выявление степени родства лиц, входящих в данную сословно-родственную социокультурную группу, объединенную общностью генеалогической составляющей $[11$, ф. 1 , оп. 1 «Воскресенский Ново-Иерусалимский монастырь 1678-1919 гг.», машинопись, 1987, с. 128].

Комплекс данного некрополя начинает погребение Святейшего Патриарха Никона. Далее лица, связанные с патриархом и их потомки: некрополь рода князей Волконских (предп. вт. пол. XVII - середина XVIII в.); некрополь дворян Нащокиных (13.03.1718 22.05.1793); некрополь князей Щербатовых, дворян Бестужевых-Рюминых и дворян Карповых (1755 - 17.11.1823); некрополь князей Черкасских, дворян Загряжских (22.03.1782 $30.05 .1847)$, некрополь князей Шаховских (06.12.1809 - 07.08.1817), некрополь дворян Бутурлиных - Приклонских - Волынских Вульф - Сухово-Кобылиных (25.10.1778 11.04.1873) и других.
Проведенное нами генеалогическое исследование позволило выдвинуть ряд версий, позволивших обосновать родство князя Александра Анофриевича Челакаева с рядом исторических персоналий, напрямую связанных с судьбой подмосковного Нового Иерусалима. В частности, нам удалось документально подтвердить родство интересующей нас личности с монастырскими ктиторами из рода князей Грузинских и их непосредственными родственниками из семьи дворян Приклонских. Итогом работы стало пополнение данного некрополя Бутурлиных - Приклонских Волынских - Вульф - Сухово-Кобылиных, вновь открытым 12-м захоронением князя А.А. Челакаева.

На протяжении последних лет по инициативе Фонда по восстановлению Воскресенского Ново-Иерусалимского монастыря в обители осуществляются масштабные работы, включающие ремонт, реставрацию, регенерацию и сохранение объекта культурного наследия. Научно-исследовательские, изыскательские и археологические работы, проводимые с 2009 г. под началом специальной Ново-Иерусалимской экспедиции Института археологии Российской академии наук, затронули также и территорию первого кладбища монастыря, где со второй половины XVIII в. начал формироваться дворянский некрополь обители [1, с. 5-6].

За период с 2009 по 2013 г. было открыто несколько неизвестных памятников, ранее полностью скрытых в земле. Так, на глубине одного метра в ходе работ были найдены два новых захоронения и надгробья. Их удалось атрибутировать, что позволило восполнить материал нашего исследования, связанного с изучением некрополя Воскресенского НовоИерусалимского монастыря в системе генеалогических [15, с. 235-237], геральдических [12, с. 138-141] и эпиграфических памятников (1656-1919) [14, c. 6-7].

Оба обнаруженных объекта представляют белокаменные саркофаги второй половины XVIII столетия. Первое: определено фактическое захоронение и выявлено новое более раннее надгробие Петра Михайловича Приклонского (22.06.1711 - 25.10.1778). До настоящего момента на северном участке старого братского кладбища был известен 


\section{ОТЕЧЕСТВЕННАЯ ИСТОРИЯ}

поздний вариант каменной плиты, принадлежащей данному лицу. Второе: неизвестное ранее захоронение и надгробие капитана князя Александра Анофриевича Челакаева. Общий составленный нами алфавитный список лиц, погребенных в обители, на данный момент составляет 370 персоналий. Князь А.А. Челакаев стал 122-м выявленным представителем дворянского происхождения, что соответствует № 109 в списке по дворянскому некрополю и № 354 в общем алфавитном списке. Ряду погребенных в монастыре и упоминаемых в настоящем исследовании персоналий также присвоены номера согласно алфавитному списку, который может изменяться с получением новых данных [13, с. 256-260].

Весьма интересен саркофаг князя А.А. Челакаева: длина -170 см; ширина 70 см и 50 см. Высоту и глубину определить не представилось возможным, поскольку сразу после обнаружения для целостности сохранения объекта в полевых условиях была проведена немедленная консервации. Особую уникальность памятнику придают рельефные изображения двух геральдических эмблем, одна из которых - ранее неизвестный герб князей Челакаевых. Первое изображение представляет круглый щит, размещенный на фоне горностаевой мантии с княжеской шапкой, соответствующей титулу погребенного. В центре щита монограмма, составленная из трех переплетенных латинских литер с инициалами. Второй рельеф - герб, на котором круглый четверочастный щит также размещен на фоне горностаевой мантии с княжеской шапкой. Проделанная в полевых условиях фотофиксация герба и сравнение его с другим сохранившимся гербом князей Чолокашвили из княжеской усыпальницы в Квашоэтской церкви в дальнейшем позволит дать детальный блазон геральдического щита, чему будет посвящена отдельная публикация.

После пояснений относительно двойственности надгробий как сложности в атрибуции конкретных личностей вернемся к рассматриваемым нами двум новым объектам из некрополя дворян Приклонских и родственных им фамилий. Обнаружение этих двух памятников дает объяснение парности (двойственности) сохранившихся надгробий. Вероятной причиной того, что памятники оказались глубоко под землей, явились работы по отсыпке земли при императоре Павле I. Именно тогда появился ров, отделивший с юга и с севера старого братского кладбища подземную церковь святых Константина и Елены. Не исключено, что в этот период ряд захоронений более раннего времени был уничтожен или перенесен на новое место. К этому времени можно отнести ситуацию с захоронениями П.М. Приклонского и князя А.А. Челокаева, когда их надгробия оказались ниже уровня земли. Впоследствии княгине Наталье Степановне Щербатовой, Петру Михайловичу Приклонскому и одной из княжон Мещерских родственники на месте прежних захоронений установили новые надгробия. С князем Александром Анофриевичем Челакаевым вышло иначе. Генеалогия данной княжеской фамилии представляется весьма малоизученной, но факт забвения захоронения князя дает возможность предполагать отсутствие у него прямых наследников или близких родственников. Между тем мы склонны усматривать неслучайность его погребения в обители. Генеалогически есть возможность соотнести князя с членами некрополя дворянских семей Бутурлиных - Приклонских - Волынских - Вульф Сухово-Кобылиных [18, с. 52], поскольку захороненный в 1789 г. князь Александр Анофриевич Челокаев лежит в непосредственной близости от погребенного в 1778 г. Петра Михайловича Приклонского. Расстояние между ними составляет не менее четырех и не более четырех с половиной метров. Стратиграфия расположения могил во время раскопок позволила допустить, что между ними сохранились еще три или четыре захоронения. Это укладывается в схему известного семейного некрополя. Четыре лица семьи Петра Михайловича Приклонского: жена Наталья (Настасья) Николаевна Приклонская, урожденная Бутурлина (28.07.1728 - 15.09.1792); младшая дочь - Екатерина Петровна Вульф, урожденная Приклонская (1756 - 08.06.1786); зять - действительный статский советник, президент Московского городового Правления Михаил Васильевич Волынский (08.10.1746 02.12.1799); старшая дочь - Анастасия Петровна Волынская, урожденная Приклонская (06.12.1755 - 15.05.1812). Их надгробия сохранились, но спорность месторасположения оче- 
видна. На протяжении ряда десятилетий в послереволюционный период истории монастыря имел место факт перемещения надгробий, поэтому обнаруженные и атрибутированные в грунтовой части некрополя захоронения дают возможность впервые определить точное место других захоронений дворянской части некрополя. В частности, это касается реальных мест погребения шести представителей трех поколений семьи Сухово-Кобылиных, члены которой являются частью фамильного некрополя Бутурлиных - Приклонских - Boлынских - Вульф. Из дворян Сухово-Кобылиных в обители упокоены дед и бабка прославленного драматурга, почетного академика отделения русского языка и словесности Александра Васильевича Сухово-Кобылина (17.09.1817, Москва - 11.03.1903, Ривьера, вилла Болье), полковник Александр Васильевич Сухово-Кобылин (12.08.1748 - 22.01.1815) и его супруга Евдокия (Авдотья) Ивановна Мусина-Пушкина (01.03.1750 - 23.02.1801). Последняя была дочерью Натальи Михайловны Приклонской (?-?), родной сестры Петра Михайловича Приклонского. Также в монастыре погребены два следующих поколения Сухово-Кобылиных: родители классика, отец полковник Василий Александрович СуховоКобылин (11.03.1784 - 11.04.1873), мать - Мария Ивановна Шепелева (1789 - 08.07.1862), брат - Иван Васильевич Сухово-Кобылин (ок. 1829 - 06.06.1849) и сестра - художница Софья Васильевна Сухово-Кобылина (1825 25.09.1867).

Для уточнения места в некрополе князя Александра Анофриевича Челакаева мы проанализировали его родственные связи как доказательство родства/свойства князя с лицами, входящими в некрополь дворянских семей Бутурлиных - Приклонских - Волынских Вульф - Сухово-Кобылиных (08.06.1786 11.04.1873). Не последним аргументом здесь является близкородственная связь князя с монастырскими ктирорами из рода князей Грузинских, непосредственными родственниками семьи Приклонских, что в итоге позволило нам сопричесть князя А.А. Челакаева в качестве 12-го лица этого семейного некрополя.

Безусловно, для погребения родство являлось весьма веской причиной [20, л. 33 об.]. Однако фактом номер один стали события
Чумного бунта 15.09.1771 (ст. стиля), одного из глобальных восстаний, вызванных эпидемией чумы (1770-1772), после чего захоронения всех сословий разрешались исключительно за камер-коллежским валом. Подобная тенденция предопределила формирование семейных и родовых усыпальниц русского дворянства в стенах подмосковных монастырей, в том числе таком, как статусный ставропигиальный Воскресенский Ново-Иерусалимский. Между тем появление целого ряда семейных захоронений обусловлено родством с семьей Нащокиных, хоронившейся в монастыре с 13.03.1718 по 22.05.1793. Возможно, фактор родства обеспечил погребение в 1755 г. их родственника князя Семена Ивановича Щербатова. Если судить по временным рамкам, то ситуация после 1772 г. дала толчок для тенденции возникновения семейных захоронений. Первой из родни Нащокиных была захоронена Анна Александровна, урожденная княжна Оболенская $(† 28.02 .1775)$, предопределив появление семейного некрополя дворян Бестужевых-Рюминых и Карповых (28.02.1775 - 17.11.1823). Появление семейного некрополя дворян Бутурлиных Приклонских - Волынских - Вульф - СуховоКобылиных относится к 25.10.1778 и связано с захоронением Петра Михайловича Приклонского. Далее погребается княгиня Н.С. Щербатова († 25.08.1780). Некрополь князей Черкасских и дворян Загряжских возникает 22.03.1782. К 06.12.1809 относится возникновение некрополя князей Шаховских.

Перечисление захоронений в обители семей, связанных родством, еще больше убеждает нас в том, что тот же родственный фактор и постчумные запрещения на захоронения в Москве могли подтолкнуть к погребению князя Александра Анофриевича Челакаева 1789 г. в Воскресенском Ново-Иерусалимском монастыре. Приведенные выше доводы объясняют, почему умерший в 1789 г. князь А.А. Челакаев не был погребен в Москве в Николо-Греческом монастыре, где зафиксированы восемь погребений представителей грузинской аристократии, относящиеся к первой половине XVIII столетия. Среди них восьмое - князя Отара Челокаева, умершего 24 февраля 1742 г. [21, с. 220]. Грузинское имя Отар тождественно русскому Онуфрий, поэтому не будем исключать возможности, что он 
может являться отцом князя А.А. Челакаева. Там же, в Николо-Греческом монастыре, в грузинской усыпальнице пятой погребенной обозначена царица Екатерина Егоровна, умершая 3 мая 1730 года, приходившаяся супругой царю Кахети Кайхосро Левоновничу. Царица по мужу приходилась теткой князю Николаю Семеновичу Багратиону (Семенову), связанному с князьями Челакаевыми. В частности, с царицей в той же степени родства состояли и родственные П.М. Приклонскому ктиторы монастыря из Грузинской династии, в екатерининское время во всех официальных бумагах упоминающиеся с титулом «принцев».

Итак, было логично видеть князя А.А. Челакаева погребенным ни в подмосковной обители, а в одном из московских монастырей, которые находились в предместье Москвы за камер-коллежским валом. В качестве примера очень бы подошел московский Донской монастырь, поэтому возникает закономерный вопрос: почему здесь не нашел места упокоения князь А.А. Челакаев? Тем более подобный вопрос окажется вполне закономерным. Эта земля с начала XVIII столетия стала излюбленным местом упокоения грузинской аристократической элиты. В его стенах нашли приют и свое последнее земное отечество 65 политических и государственных деятелей Грузии. Согласно изысканиям Д.В. Лобанова, в целом на территории монастыря похоронено 86 представителей грузинской колонии в Москве [9, с. 30-31]. Именно Донской монастырь стал последним пристанищем для погребения потомков таких княжеских фамилий, как Дадиани, Амилахвари, Ратишвили, Багратион-Имеретинские, Туркестановы и Тактакишвили. Весьма примечательно и то, что не в Воскресенском Ново-Иерусалимском монастыре, а в Донском начиная с первой половины XVIII века стали хоронить обосновавшихся в России представителей царского Кахетинского дома Багратионов, поэтому было бы более логично представить князя Александра Анофриевича Челакаева погребенным не только рядом с соплеменниками, сколько даже с кровными царственными родственниками, чьим усердием был образован обширный грузинский некрополь. Так, в подклете Большого собора Донского монастыря 27.03.1711 первым из московских Багратио- нов упокоился известный деятель петровского времени Имеретинский царевич Александр Арчилович (1667/74 - 1711), который приходился сыном Арчилу II Вахтанговичу, царю Имерети и Кахети. Он, в свою очередь, являлся сыном Вахтанга V (Шах-Наваза) первого царя Картли из второго Грузинского (Мухранского) царского дома [6, с. 45].

Обустраивая семейную усыпальницу, проживавший в Москве царь Арчил II уже 05.04.1711, в скором времени после погребения сына, переносит из Новодевичьего монастыря и захоранивает в Донском монастыре рядом с ним останки его первой супруги царевны Феодосии Ивановны, урожденной Милославской. Последнее, вероятно, делалось с очевидной целью не столько подчеркнуть свою сопричастность к боярскому клану, сколько через сноху указать на собственное родство с царским домом Романовых. В это же время в усыпальницу переносятся останки двух его сыновей - царевичей Давида († 1688 г.) и Мамуки († 1693 г.). В 1712 г. на месте упокоения членов своей семьи царь Арчил II основал храм в честь Сретения Господня. Здесь 19.04.1713 предали земле и самого государя Имерети и Кахети [3, с. 20-21]. Данные нами пространные уточнения, связанные с захоронениями членов семьи владетелей Имерети и Кахети, интересны еще и тем, что и царь Арчил II приходился достаточно близким родственником семье князей Челакаевых, поскольку упоминаемый нами выше князь Николай Семенович Багратион (Семенов) доводился Арчилу II двоюродным внуком.

На то, что семья принцев Грузинских имела тесную связь с Подмосковным Новым Иерусалимом, проливает свет рукопись архимандрита Аполлоса (Байбакова), датированная 1777 годом. Текст документа доносит список монастырских ктиторов, где фигурирует имя матери Софьи Левоновны Приклонской, царевны Александры Яковлевны Грузинской [20, л. 22 об.], урожденной княжны Сибирской.

Не менее интересно, что родной брат погребенного в обители князь Филипп Анофриевич Челакаев в 1765 г. в Звенигородском уезде и непосредственной близости от монастыря стал владельцем деревень Назарово (Троицкое) и Медведково (в 30,5 - 32,5 км се- 
веро-западнее современного города Истра), которые с 1758 г. числились за князем Николаем Семеновичем Багратионом (Семеновым) [8, с. 742-743]. Последнего в официальных документах на протяжении всей жизни преследовало двойственное употребление фамилии. Не лишним будет пояснить, что ему как внебрачному сыну грузинского царевича Симона Левановича (Симеона Леоновича) в Российской империи было отказано писаться царевичем и употреблять родовую фамилию Багратион. Определением Сената от 24.02.1741 поручику Сибирского полка Николаю Багратиону повелевалось писаться по объявленному своему отцу отыменной фамилией Семенов с правом употребления княжеского титула [2, с. 72].

Первый князь Семенов умер после 1776 г., а в 1765 г. деревни по закладной отходят к брату князя Александра Анофриевича Челакаева, который мог являться кредитором или лицом, выкупившим закладные на обеспечение займа у кредиторов своего родственника, учитывая, что князь Н.С. Багратион (Семенов) принадлежал к старшей карталинской ветви князей Грузинских, следовательно, был связан родством с ктиторами монастыря, доводясь двоюродным дядей мужу царевны Александры Яковлевны Грузинской, матери Софьи Левоновны Приклонской [4, с. 11-13].

На связь князя Александра Анофриевича Челакаева с родственниками князей Грузинских (ктиторами) указывает и другой пример. Двоюродная сестра князя Николая Семеновича Багратиона (Семенова) царица Тамара (1698-1746) была женой царя Картли и Кахети Теймураза II, а также приходилась теткой царевне и двоюродной бабкой С.Л. Приклонской. Интересно, что супруг царицы - царь Теймураз II, принадлежавший к кахетинской ветви Багратионов, являлся близким родственником князя А.А. Челакаева. Теймураз II был сыном царя объединенных Картли и Кахетии Ираклия I от брака с царицей Анной Шермазановной, урожденной княжной Челокаевой [6, с. 42-43, 47, 66-67], предки которой начиная со второй половины XV в. неоднократно состояли в родстве с царями Кахети. Согласно князю П.В. Долгорукову, в Кахетинском царстве старшие представите- ли дома князей Челокаевых наравне с такими же старшими членами княжеских семей Андроникашвили (Андрониковых) и Баргатион-Мухранских (Мухранели) считались князьями первой степени [5, с. 63]. Вероятно, в западном эквиваленте это могло приравниваться к генеалогическому статусу, равному принцам крови.

Близость расположения захоронения князя Александра Анофриевича Челакаева с могилой Петра Михайловича Приклонского, возможно, обусловлена тем, что их объединяла определенная степень родства. И оно существовало в действительности. Племянник Петра Михайловича, Андрей Богданович Приклонский, состоял в браке княжной Софьей Левоновной Грузинской [10, с. 127]. Заслуживает внимания факт, что упомянутая наследница правителей Картли, внучка царя Баграта и правнучка царя Вахтанга VI, Софья Левоновна Приклонская находилась в переписке с настоятелями обители. Об этом свидетельствует документальное упоминание об утраченном ныне письме за 1775 г. [11, ф. 1, оп. 1, «Воскресенский Ново-Иерусалимский монастырь 1678-1919 гг.», машинопись, 1987, с. 111 ; ф. 1, оп. 1 , д. 389].

Факт обнаружения саркофага князя Александра Анофриевича Челакаева в некрополе Воскресенского Ново-Иерусалимского монастыря совместно с изучением материалов, связанных с отечественной генеалогией, геральдикой и эпиграфикой, позволили нам отнести вновь открытое захоронение к некрополю Бутурлиных - Приклонских - Волынских Вульф - Сухово-Кобылиных.

\section{СПИСОК ЛИТЕРАТУРЫ}

1. Беляев, Л. А. Новый Иерусалим и другие эталонные памятники археологии нового времени в России / Л. А. Беляев // От Смуты к Империи. Новые открытия в области археологии и истории России XVI-XVIII в. : тез. докл. науч. конф. - М. : ИА РАН, 2013. - С. 5-6.

2. Васильевич (Любимов), С. В. Титулованные роды Российской империи: опыт подробного перечисления всех титулованных российских дворянских фамилий, с указанием происхождения каждой фамилии, а также времени получения титула и угверждения в нем : в 2 т. / С. В. Васильевич. -СПб. : Тип. т-ва «Общественная польза», 1910.- Т. 1. -296 с. 
3. Гулордава, Д. А. Грузинский некрополь Донского монастыря (к истории поселения грузин в России) / Д. А. Гулордава // Россия и зарубежье: генеалогические связи : тез. I Междунар. генеал. коллоквиум (Москва, 29.XI - 4.XII.1999). - М. : ГИМ, 1999. - C. 20-21.

4. Долгоруков, П. В. Российская родословная книга, издаваемая князем Петром Долгоруковым : в 4 ч. / П. В. Долгоруков. - СПб. : Типография Карла Вингебера, 1855. - Ч. 2. - 328 с.

5. Долгоруков, П. В. Российская родословная книга, издаваемая князем Петром Долгоруковым: в 4 ч. / П. В. Долгоруков. - СПб. : Типография Карла Вингебера, 1856. - Ч. 3. -524 с.

6. Думин, С. В. Дворянские роды Российской империи: в 4 т. Т. 3. Князья / С. В. Думин, П. Х. Гребельский ; под ред. С. В. Думина. - М. : Ликоминвест, 1996. -280 с.

7. Зеленская, Г. М. Некрополь Нового Иерусалима. Историко-семиотическое исследование / Г. М. Зеленская, А. В. Святославский. - М. : Древлехранилище, 2006. $-418 \mathrm{c}$.

8. Истринская земля / А. А. Зилов [и др.] ; под ред. Л. В. Гладкова. - М. : Энциклопедия сел и деревень, 2004. -850 с.

9. Лобанов, Д. В. Некрополь Донского монастыря и его значение для нашего времени / Д. В. Лобанов // Тенденции формирования науки нового времени : сб. ст. Междунар. науч.-практ. конф. (2728 дек. 2013 г.) : в 4 ч. / отв. ред. А. А. Сукиасян. Уфа : РИЦ БашГУ, 2014. - Ч.3. - С. 29-32.

10. Лобанов-Ростовский, А. Б. Русская родословная книга : в 2 т. / А. Б. Лобанов-Ростовский. СПб. : Тип. А.С. Суворина, 1895. - Т. 2. - 488 с.

11. Музейно-выставочный комплекс Московской области. - Ф. 1.

12. Мурзин-Гундоров, В. В. Геральдическая составляющая некрополя Ново-Иерусалимского монастыря / В. В. Мурзин-Гундоров // Актуальные проблемы гуманитарных наук : межвуз. сб. науч. работ. - М. : РГСУ, 2007. - Вып. 3. - С. 138-141.

13. Мурзин-Гундоров, В. В. Захоронение князя Александра Анофриевича Челакаева (Челокаева) в некрополе Воскресенского Ново-Иерусалимского монастыря / В. В. Мурзин-Гундоров // Вспомогательные и специальные науки истории в XX начале XXI в.: призвание, творчество, общественное служение историка : материалы XXVI Междунар. науч. конф. памяти Сигурда Оттовича Шмидта (Москва, 14-15 апр. 2014 г.). - М. : РГГУ, 2014. C. 256-260.

14. Мурзин-Гундоров, В. В. Исследовательское поле Ново-Иерусалимского некрополя / В. В. Мурзин-Гундоров // Приложение к журналу «Ученые записки Российского государственного социального университета». - М. : РГСУ, 2007. -№ 1 (53). -С. 6-7.
15. Мурзин-Гундоров, В. В. Ново-Иерусалимская ветвь рода дворян Татищевых / В. В. МурзинГундоров // Единство гуманитарного знания: новый синтез : материалы XIX Междунар. науч. конф. - М. : Изд. РГГУ, 2007. - С. 235-237.

16. Мурзин-Гундоров, В. В. Обзор документов из хранилищ Воскресенского Ново-Иерусалимского монастыря (вторая половина XVII - начало XX века) / В. В. Мурзин-Гундоров // Материалы XV Всероссийской научной конференции «Писцовые книги и другие массовые источники XVIXX веков» к столетию П.А. Колесникова. - М. : Древлехранилище, 2008. - С. 224-232.

17. Мурзин-Гундоров, В. В. Фамильные погребения некрополя монастыря Нового Иерусалима / В. В. Мурзин-Гундоров // Актуальные проблемы гуманитарных наук : межвуз. сб. науч. работ. - М. : РГСУ, 2007. - Вып. 3. - С. 141-144.

18. Программы конференций 1997-2013 гг. // XVI Петербургские генеалогические чтения. СПб. : РНБ, 2013. -55 c.

19. Российский государственный архив древних актов. - Ф. 1625 (Воскресенский Новоиерусалимский монастырь). - Оп. 1. - Д. 34. Описи церковного и ризничного имущества монастыря, 1875 г.

20. Российский государственный исторический архив. - Ф. 834 (Рукописи Синода). - Оп. 2. Д. 1762. Исторические достопамятности о начале и происшествиях старопигиального Воскресенского монастыря, нареченного Новым Иерусалимом. Сочинил архимандрит Аполлос, 1777 г.

21. Татишвили, В. И. Грузины в Москве 1653 1722 / В. И. Татишвили. - Тбилиси : Заря Востока, 1959. $-230 \mathrm{c}$.

22. Шереметьевский, В. В. Русский провинциальный некрополь великого князя Николая Михайловича. Т. 1 : Губ. Архангельская, Владимирская, Вологодская, Костромская, Московская, Новгородская, Олонецкая, Псковская, С.-Петербургская, Тверская и Ярославская, с присоединением Валаамского и Коневского монастырей / В. В. Шереметьевский. - М. : Типо-Литография Т-ва И. Н. Кушнерев и Ко, 1914. -1008 с.

\section{REFERENCES}

1. Belyaev L.A. Novyy Ierusalim i drugie etalonnye pamyatniki arkheologii novogo vremeni $\mathrm{v}$ Rossii [New Jerusalem and Other Archaeological Reference Monuments of the New Time in Russia]. Ot Smuty k Imperii. Novye otkrytiya v oblasti arkheologii i istorii Rossii XVI-XVIII vv. [From the Time of Troubles to the Empire. New Discoveries in the Field of Archeology and History of Russia in the 
16-18th Centuries]. Moscow, IA RAN Publ., 2013, pp. 5-6.

2. Vasilevich (Lyubimov) S.V. Titulovannye rody Rossiyskoy imperii: opyt podrobnogo perechisleniya vsekh titulovannykh rossiyskikh dvoryanskikh familiy, s ukazaniem proiskhozhdeniya kazhdoyfamilii, a takzhe vremeni polucheniya titula $i$ utverzhdeniya $v$ nem: $v 2 t$. [Titled Families of the Russian Empire: Experience of a Detailed Listing of All Titled Russian Noble Families, With an Indication of the Origin of Each Name, as Well as the Time of Receipt and Approval of Its Title]. Saint Petersburg, Tip. t-va "Obshchestvennaya polza", 1910, vol. 1. $296 \mathrm{p}$.

3. Gulordava D. A. Gruzinskiy nekropol Donskogo monastyrya ( $\mathrm{k}$ istorii poseleniya gruzin $\mathrm{v}$ Rossii) [Georgian Necropolis of Donskoy Monastery (the History of the Settlement of Georgians in Russia)]. Rossiya i zarubezhye: genealogicheskie svyazi : tez. I Mezhdunar. geneal. kollokvium (Moskva, 29.XI4.XII.1999) [Russia and Abroad: Genealogical links. Theses of the $1^{\text {st }}$ International Genealogical Seminar (Moscow, November 29 -December 4, 1999)]. Moscow, GIM Publ., 1999, pp. 20-21.

4. Dolgorukov P.V. Rossiyskaya rodoslovnaya kniga, izdavaemaya knyazem Petrom Dolgorukovym: $v 4 \mathrm{ch}$. [Russian Genealogy Book Issued by Prince Petr Dolgorukov: in 4 Parts]. Saint Petersburg, Tipografiya Karla Vingebera Publ., 1855. 328 p.

5. Dolgorukov P.V. Rossiyskaya rodoslovnaya kniga, izdavaemaya knyazem Petrom Dolgorukovym: $v 4$ ch. [Russian Genealogy Book Issued by Prince Petr Dolgorukov: in 4 Parts]. Saint Petersburg, Tipografiya Karla Vingebera Publ., 1856, part 3. 524 p.

6. Dumin S.V., Grebelskiy P.Kh. Dvoryanskie rody Rossiyskoy imperii: v 4 t. T. 3. Knyazya [Noble Generations of the Russian Empire: in 4 vols. Vol. 3. Princes]. Moscow, Likominvest Publ., 1996. 280 p.

7. Zelenskaya G.M., Svyatoslavskiy A.V. Nekropol Novogo Ierusalima. Istorikosemioticheskoe issledovanie [The Necropolis of the New Jerusalem. Historical and Semiotic Research]. Moscow, Drevlekhranilishche Publ., 2006. 418 p.

8. Zilov A.A., Gladkov L.V., et al. Istrinskaya zemlya [Istrinskaya Land]. Moscow, Entsiklopediya sel i dereven Publ., 2004. 850 p.

9. Lobanov D.V. Nekropol Donskogo monastyrya i ego znachenie dlya nashego vremeni [The Necropolis of Donskoy Monastery and Its Significance for Our Time]. Sukiasyan A.A., ed. Tendentsii formirovaniya nauki novogo vremeni: $s$. st. Mezhdunar. nauch.-prakt. konf. (27-28 dek. 2013 g.): $v 4 \mathrm{ch}$. [Trends in the Formation of Modern Science: Collected Articles of Scientific and Practical Conference (December 27-28, 2013): in 4 Parts]. Ufa, RITs BashGU, 2014, part 3, pp. 29-32.
10. Lobanov-Rostovskiy A.B. Russkaya rodoslovnaya kniga [Russian Genealogy Book]. Saint Petersburg, Tip. A.S. Suvorina, 1895, vol. 2. 488 p.

11. Muzeyno-vystavochnyy kompleks Moskovskoy oblasti [Museum and Exhibition Complex of the Moscow Region], F. 1.

12. Murzin-Gundorov V.V. Geraldicheskaya sostavlyayushchaya nekropolya Novo-Ierusalimskogo monastyrya [Heraldic Component of the Necropolis of the New Jerusalem Monastery]. Aktualnye problemy gumanitarnykh nauk: mezhvuz. sb. nauch. rabot [Current Problems of the Humanities: Interuniversity Collection of Scientific Works]. Moscow, RGSU Publ., 2007, iss. 3, pp. 138-141.

13. Murzin-Gundorov V.V. Zakhoronenie knyazya Aleksandra Anofrievicha Chelakaeva (Chelokaeva) v nekropole Voskresenskogo Novo-Ierusalimskogo monastyrya [Burial of Prince Alexander Anofrievich Chelakaev in the Necropolis of the New Jerusalem Monastery]. Vspomogatelnye $i$ spetsialnye nauki istorii $v X X-$ nachale XXI v.: prizvanie, tvorchestvo, obshchestvennoe sluzhenie istorika: materialy XXVI Mezhdunar. nauch. konf. pamyati Sigurda Ottovicha Shmidta (Moskva, 14-15 apr. 2014 g.) [Auxiliary and Special Sciences of History in the 20th Beginning of the 21st Century: Vocation, Creativity, Public Service of the Historian: Proceedings of the VI International Scientific Conference in Memory of Sigurd Ottovich Schmidt (Moscow, April 14-15, 2014)]. Moscow, RGGU Publ., 2014, pp. 256-260.

14. Murzin-Gundorov V.V. Issledovatelskoe pole Novo-Ierusalimskogo nekropolya [The Research Field of the New Jerusalem Necropolis]. Prilozhenie $k$ zhurnalu "Uchenye zapiski Rossiyskogo gosudarstvennogo sotsialnogo universiteta”, 2007, no. 1 (53), pp. 6-7.

15. Murzin-Gundorov V.V. Novo-Ierusalimskaya vetv roda dvoryan Tatishchevykh [New Jerusalem Branch of the Noble Family of the Tatishchevs]. Edinstvo gumanitarnogo znaniya: novyy sintez: materialy XIX Mezhdunar. nauch. konf. [The Unity of Human Knowledge: a New Synthesis: Proceedings of the 19th International Scientific Conference]. Moscow, RGGUPubl., 2007, pp. 235-237.

16. Murzin-Gundorov V.V. Obzor dokumentov iz khranilishch Voskresenskogo Novo-Ierusalimskogo monastyrya (vtoraya polovina XVII - nachalo XX veka) [Review of Documents From the Archive of the New Jerusalem Monastery (Second Half of the 17th- the Beginning of 20th Centuries)]. Materialy $X V$ Vserossiyskoy nauchnoy konferentsii "Pistsovye knigi i drugie massovye istochniki XVI-XX vekov" [Proceedings of the 15th All-Russian Scientific Conference "Scribe Books and Other Public Resources of the 16th20th Centuries]. Moscow, DrevlekhranilishchePubl., 2008, pp. 224-232. 


\section{ОТЕЧЕСТВЕННАЯ ИСТОРИЯ}

17. Murzin-Gundorov V.V. Familnye pogrebeniya nekropolya monastyrya Novogo Ierusalima [Family Burials of Necropolis of the New Jerusalem Monastery]. Aktualnye problemy gumanitarnykh nauk: mezhvuz. sb. nauch. rabot [Current Problems of the Humanities: Interuniversity Collection of Scientific Works]. Moscow, RGSU Publ., 2007, iss. 3, pp. 141-144.

18. Programmy konferentsiy 1997-2013 gg. [Conference Programme of 1997-2013]. XVI Peterburgskie genealogicheskie chteniya [16th Petersburg Genealogical Readings]. Saint Petersburg, RNB Publ., 2013. 55 p.

19. Rossiyskiy gosudarstvennyy arkhiv drevnikh aktov. - F. 1625 (Voskresenskiy Novoierusalimskiy monastyr) [Russian State Archive of Ancient Acts. F. 1625. (Voskresensky New Jerusalem Monastery)], Op. 1, D. 34. Inventories of Church and Retail Property Monastery, 1875.

20. Rossiyskiy gosudarstvennyy istoricheskiy arkhiv. - F. 834 (Rukopisi Sinoda) [Russian State Historical Archive. F. 834. Synod Manuscripts], Op. 2,
D. 1762. Historical Memorability of the Beginning and Incidents of Resurrection Monastery. Composed by Archimandrite Apollos, 1777.

21. Tatishvili V. I. Gruziny v Moskve 1653-1722 [Georgians in Moscow 1653-1722]. Tbilisi, Zarya Vostoka Publ., 1959. 230 p.

22. Sheremetevskiy V.V. Russkiy provintsialnyy nekropol velikogo knyazya Nikolaya Mikhaylovicha. T. 1 : Gub. Arkhangelskaya, Vladimirskaya, Vologodskaya, Kostromskaya, Moskovskaya, Novgorodskaya, Olonetskaya, Pskovskaya, S.Peterburgskaya, Tverskaya i Yaroslavskaya, s prisoedineniem Valaamskogo $i$ Konevskogo monastyrey [Russian Provincial Necropolis of Grand Prince Nikolay Mikhaylovich. Vol. 1: Provinces: Arkhangelskaya, Vladimirskaya, Vologodskaya, Kostromskaya, Moskovskaya, Novgorodskaya, Olonetskaya, Pskovskaya, S.-Peterburgskaya, Tverskaya and Yaroslavskaya with Valaam and Konev Monastaries]. Moscow, Tipo-Litografiya T-va I.N. Kushnerev and Co., 1914. 1008 p. 